\title{
Tuotantosuunnan muutoksen vaikutus savipellolta tulevaan ravinne- ja kiintoainekuormitukseen
}

\author{
Jyrki Nurminen ${ }^{1)}$, Maija Paasonen-Kivekäs²), Helena Äijö3), Inkeri Seppälä4), Harri Koivusalo5) \\ ${ }^{1)}$ Salaojituksen tutkimusyhdistys ry, Simonkatu 12 A 11, 00100 Helsinki, jyrki.nurminen@aalto.fi \\ 2) Sven Hallinin tutkimussäätiö sr, Simonkatu 12 A 11, 00100 Helsinki, maija.paasonen@hallin.fi \\ 3) Salaojayhdistys ry, Simonkatu 12 A 11, 00100 Helsinki, helena.aijo@salaojayhdistys.fi \\ 4) Aalto-yliopisto, Insinööritieteiden korkeakoulu, inkeri.seppala@aalto.fi \\ 5) Aalto-yliopisto, Insinööritieteiden korkeakoulu, Tietotie1 E, 02150,harri.koivusalo@aalto.fi
}

Tutkimuksessa oli tavoitteena selvittää, miten valunta ja valumavesien pitoisuudet sekä huuhtoumat muuttuvat siirryttäessä tavanomaisesta viljanviljelystä nurmiviljelyyn ja laidunnukseen. Tutkimus toteutettiin seuraamalla Gårdskulla Gårdin tutkimusalueen kahta peltolohkoa Siuntion Kirkkojoen varrella. Alueiden maalaji on savea (HeS, HsS ja AS). Alueen 1 (5.7 ha) keskikaltevuus on noin $1 \%$ ja Alueen 2 (4.7 ha) noin 5 \%. Lohkot on salaojitettu 1940-luvulla keskimäärin 16 metrin ojavälillä. Vuosina 2007-2010 koealueilla viljeltiin kevät- ja syysviljoja kivennäislannoitteita ja tavanomaisia muokkausmenetelmiä käyttäen. Syksystä 2011 lähtien Alue 1 on ollut jatkuvasti nurmella ja Alue 2 lihakarjan laitumena keväästä 2011 lähtien. Tuotantosuunnan muutoksen yhteydessä koealueilla siirryttiin luomutuotantoon. Alueilla on mitattu salaoja- ja pintakerrosvaluntaa jatkuvatoimisesti. Valumavesien kokoomanäytteistä on analysoitu seuraavat pitoisuudet: kokonaistyppi, ammoniumtyppi, nitriitti- ja nitraattityppi, kokonaisfosfori, liukoinen epäorgaaninen fosfori $\left(\mathrm{PO}_{4}-\mathrm{P}\right)$ ja kiintoaine. Edelleen jatkuvat mittaukset aloitettiin syksyllä 2007. Tämän tutkimuksen aineisto on vuosilta 20082016. Molemmilla koealueilla salaojavalunta muodosti 80-90 \% mitatusta valunnasta (salaojat+pintakerros) sekä ennen tuotantosuunnan muutosta että sen jälkeen. Pintakerrosvalunnan mittauksissa oli kuitenkin useana keväänä epävarmuutta, etenkin Alueella 2. Tuotantosuunnan muutos näkyi molemmilla koealueilla kokonaistyppikuorman $(\mathrm{s}+\mathrm{p})$ noin 70 \% vähenemisenä aikaisemmasta. Typpihuuhtouma nurmelta (Alue 1) oli keskimäärin $5 \mathrm{~kg} \mathrm{ha}^{-1}$ ja laidunnurmelta (Alue 2) $7 \mathrm{~kg} \mathrm{ha}^{-1}$ vuodessa. Kokonaisfosforikuormissa (ka. $0.44 \mathrm{~kg} \mathrm{ha}^{-1} \mathrm{a}^{-1}$ ) ei ollut eroa nurmen ja viljan välillä. Laidunnurmen fosforikuorma (1.3 $\left.\mathrm{kg} \mathrm{ha}^{-1} \mathrm{a}^{-1}\right)$ oli vajaa $70 \%$ viljanviljelyn keskikuormasta. Myös kiintoainekuormat vähenivät siirryttäessä viljanviljelystä nurmiviljelyyn ja laidunnukseen. Nurmiviljelyn keskimääräinen vuotuinen kiintoainekuorma, $740 \mathrm{~kg} \mathrm{ha}^{-1}$, oli $90 \%$ viljanviljelyn kuormasta. Laidunalueella vastaavat luvut olivat $710 \mathrm{~kg} \mathrm{ha}^{-1}$ ja noin $50 \%$. Suurin ero oli liukoisen epäorgaanisen fosforin huuhtoumissa. Laidunnurmella pintakerrosvalunnan keskimääräinen kuorma (0.31 kg ha $\left.\mathrm{kg}^{-1} \mathrm{a}^{-1}\right)$ oli 7-kertainen viljanviljelyvuosiin verrattuna. Salaojavalunnan keskimääräiseen huuhtoumaan $\left(0.40 \mathrm{~kg} \mathrm{ha}^{-1} \mathrm{a}^{-1}\right)$ muutos laitumeksi ei vaikuttanut. Eri valuntareittien yhteenlaskettu $\mathrm{PO}_{4^{-}}$ P - kuorma (ka. $0.69 \mathrm{~kg} \mathrm{ha}^{-1} \mathrm{a}^{-1}$ ) laidunnurmelta oli viljanviljelyyn nähden 1.6-kertainen. Nurmiviljelystä vastaava kuorma (0.12 $\left.\mathrm{kg} \mathrm{ha}^{-1} \mathrm{a}^{-1}\right)$ oli aikaisempaan verrattuna 1.5-kertainen. Kuormituksen kasvu johtui pääosin kohonneista pintakerrosvalunnan pitoisuuksista.

Tutkimusta ovat rahoittaneet Salaojituksen Tukisäätiö sr ja hankkeessa mukana olleet laitokset. Vuosina 2007-2013 rahoittajana oli myös maa- ja metsätalousministeriö ja 2011-2013 Maa- ja vesitekniikan tuki ry.

Asiasanat: savipellot, vesistökuormitus, tuotantosuunnan muutos 


\section{Johdanto}

Tutkimushankkeen tavoitteena on selvittää veden ja aineiden kulkeutumisreittejä ja kuormitusta sekä tuotantosuunnan muutoksen vaikutuksia kuormitukseen peltolohkon mittakaavassa. Mittauksia on tehty kahdella salaojitetulla savipellolla syksystä 2007 lähtien. Vuosina 2007-2013 tutkimus oli osa "Pellon vesitalouden optimointi” (PVO ja PVO2) -hankkeita (Vakkilainen ym. 2008 ja 2010, Äijö ym. 2014). Koealueiden hydrologiaa ja vesitasetta sekä eroosiota ja kiintoaineen kulkeutumista on tutkittu myös laskennallisesti matemaattista mallia käyttäen (Turunen ym. 2015 ja 2017). Tämän tutkimuksen tavoitteena oli selvittää vuosien 2008-2016 mittausten perusteella, miten siirtyminen tavanomaisesta viljanviljelystä luonnonmukaiseen nurmiviljelyyn ja laidunnukseen vaikuttaa valuntaan ja valumavesien pitoisuuksiin sekä ravinne- ja kiintoainekuormiin. Tutkimuksessa on tarkasteltu vuositasolla tapahtuneita muutoksia. Fosforikuormituksen vuodenaikaisia muutoksia on käsitellyt Seppälä (2017). Hankkeen tutkimusraportti julkaistaan keväällä 2018 (Nurminen ym. 2018).

\section{Materiaalit ja menetelmät}

Kaksi lohkotason tutkimuskohdetta sijaitsee Gårdskulla Gårdin tilalla Siuntiossa Kirkkojoen valumaalueella. Koekenttä perustettiin PVO-hankkeessa loppusyksyllä 2007 (Vakkilainen ym. 2008 ja 2010). Kirkkojoen veden laatua ja kuormitusta on tutkittu Teknillisen korkeakoulun (nykyisin osa Aaltoyliopistoa) toimesta eri hankkeissa 1970-luvulta lähtien (Pekkarinen 1979, Maasilta ym. 1980, Nurminen ym. 2007, Vento 2008).

Tutkimuslohkot (alue 1 ja alue 2) sijaitsevat Kirkkojoen molemmin puolin ja niiden suojavyöhykkeet rajoittuvat jokeen. Alueen 1 (kaltevuus noin 1\%) salaojastojen pinta-ala on 5.7 ja alueen 2 (kaltevuus noin 5\%) 4.7 hehtaaria. Salaojitus on tehty tiiliputkin 1940-luvulla noin 16 metrin ojavälillä, ja sen jälkeen salaojia on paikoitellen korjattu. Koealueiden maalaji on savea (hiue-, hiesuja aitosavea). Lohkojen salaoja- ja pintakerrosvaluntavedet johdetaan koealueilta mittauskaivoon, josta ne purkautuvat Kirkkojokeen.

Vuosina 2007-2010 molemmilla koealueilla viljeltiin syys- tai kevätviljoja (syysvehnä, vehnä, mallasohra), kivennäislannoitteita ja tavanomaisia muokkausmenetelmiä (kyntö ja kevytmuokkaus) käyttäen, mutta niiden viljelytoimenpiteet poikkesivat jonkin verran toisistaan. Alue 2 on ollut lihakarjan laitumena keväästä 2011 lähtien. Tutkimusalue on osa isompaa aluetta, jolla on laiduntanut 60 eläintä touko-syyskuun välisenä aikana. Karjalle on annettu lisärehua laidunnuskauden loppupuolella. Alue 1 on ollut jatkuvasti nurmella syksystä 2011 lähtien. Tuotantosuunnan muutoksen yhteydessä koepelloilla siirryttiin luonnonmukaiseen viljelyyn. Alueen 1 nurmella on tehty voikukkien mekaaninen käsittely keväisin, mutta aluetta ei ole lannoitettu. Sato on korjattu kerran kaudessa tuorerehuksi. Pintakerroksen (0-20 cm) fosforiluku (v. 2013) oli alueella $110.8 \mathrm{mg} \mathrm{l}^{-1}$ ja alueella 214.6 $\mathrm{mg} \mathrm{l}^{-1}$.

Vuosina 2008-2016 mitattiin molemmilla koelohkoilla seuraavia muuttujia: pintakerros- ja salaojavalunta (jatkuva mittaus 15 minuutin välein), kiintoaineen, kokonaisfosforin (Kok-P), liukoisen epäorgaanisen fosforin $\left(\mathrm{PO}_{4}-\mathrm{P}\right)$, kokonaistypen (Kok-N), nitriitti- ja nitraattitypen $\left(\mathrm{NO}_{2}-\mathrm{N}+\mathrm{NO}_{3}-\mathrm{N}\right)$ ja ammoniumtypen $\left(\mathrm{NH}_{4}-\mathrm{N}\right)$ pitoisuudet pintakerros- ja salaojavalunnassa (automaattinen näytteenotto virtauksen suhteen, laboratorioanalyysit), sadanta (jatkuva mittaus 15 minuutin välein), pohjaveden pinnan korkeus (manuaalinen mittaus), lumen syvyys ja vesiarvo (manuaalinen mittaus, lumikepit ja lumipuntari) ja roudan syvyys (manuaalinen mittaus, metyleenisiniputket). Vesinäytteet analysoitiin TKK:n / Aalto-yliopiston Insinööritieteiden korkeakoulun vesilaboratoriossa. Mittaus- ja analyysimenetelmät on kuvattu yksityiskohtaisesti julkaisuissa Vakkilainen ym. (2008, 2010).

\section{Tulokset}

\section{Valunta}

Koekentältä mitatut vuotuiset sadesummat (korjatut) vaihtelivat välillä 565-844 mm. Alueella 1 vuosivalunnan (salaoja+pintakerros) vaihteluväli oli 209-520 mm ja alueella 2 105-400 mm. Sekä eniten (2008) ja että vähiten valuntaa muodostanut vuosi (2009) osui viljanviljelyjaksolle. Loivemmalla 
koealueella 1 (kaltevuus 1\%) salaojavalunta muodosti vuosina 2008-2016 keskimäärin $91 \%$ (vaihteluväli 82-98\%) mitatusta kokonaisvalunnasta (salaoja- ja pintakerrosvalunnan summa). Kaltevammalla alueella 2 (5\%) salaojavalunnan osuus oli 85\% (71-93\%). Mitatusta kokonaisvalunnasta $(\mathrm{s}+\mathrm{p})$ syntyi koealueella 1 loka-huhtikuussa keskimäärin 89\% ja koealueella 2 95\%.

\section{Valunta ennen tuotantosuunnan muutosta ja sen jälkeen}

Koealueella 1 kokonaisvalunnan $(\mathrm{s}+\mathrm{p})$ osuus sadannasta oli tuotantosuunnan muutoksen jälkeisinä vuosina keskimäärin 15\% suurempi kuin ennen muutosta. Pintakerrosvalunnan osuus kasvoi suhteellisesti enemmän kuin salaojavalunnan. Vuodet 2008-2011 olivat keskimäärin sateisempia (706 $\mathrm{mm}$ ) kuin vuodet 2012-2016 (675 mm). Salaojavalunnan ja pintakerrosvalunnan osuudet eivät tuotantosuunnan vaihtuessa käytännössä muuttuneet, vuosina 2008-2011 salaojavalunnan osuus oli 91\% ja vuosina 2012-2016 90\%.

Kaltevammalla (5\%) koealueella 2 kokonaisvalunnan osuus sadannasta oli muutoksen jälkeisinä vuosina keskimäärin $11 \%$ aikaisempaa suurempi. Salaojavalunnan osuus sadannasta ei käytännössä muuttunut, mutta pintakerrosvalunnan osuus sadannasta kasvoi 5 prosenttiyksikköä. Jaksojen 20082010 sekä 2011-2016 keskimääräiset vuosisadannat olivat 685 ja 690 mm. Pintakerrosvalunnan osuus kokonaisvalunnasta kasvoi, sen osuus oli ennen muutosta 8\% ja sen jälkeen 22\%.

Taulukko 1. Alueen 1 (a) ja alueen 2 (b) valuntavesien kokonaistypen (Kok-N), kokonaisfosforin (Kok-P), liukoisen epäorgaanisen fosforin $\left(\mathrm{PO}_{4}-\mathrm{P}\right)$ ja kiintoaineen valunnalla painotetut pitoisuudet sekä kuormien vuosikeskiarvot ennen tuotantosuunnan muutosta ja sen jälkeen. Alueella 1 vuodet ennen ovat 2008-2011 (vilja) ja jälkeen 2012-2016 (nurmi) ja alueella 2 vastaavat jaksot, 2008-2010 (vilja) ja 2011-2016 (laidun). Ylimpänä on jaksojen vuosisadantojen (korjatut) keskiarvot.

ALUE 1 a)

ALUE 2 b)

\begin{tabular}{|c|c|c|c|c|c|c|c|c|}
\hline \multirow{3}{*}{ Sadanta, mm } & \multicolumn{2}{|c|}{ Vuodet 2008 - 2011} & \multirow{2}{*}{\multicolumn{2}{|c|}{$\begin{array}{l}\text { Vuodet } 2012-2016 \\
\quad 675\end{array}$}} & \multirow{2}{*}{\multicolumn{2}{|c|}{$\begin{array}{l}\text { Vuodet } 2008-2010 \\
\quad 685\end{array}$}} & \multirow{2}{*}{\multicolumn{2}{|c|}{$\begin{array}{l}\text { Vuodet } 2011-2016 \\
690\end{array}$}} \\
\hline & 706 & & & & & & & \\
\hline & Salaojat & Pinta & Salaojat & Pinta & Salaojat & Pinta & Salaojat & Pinta \\
\hline Valunta, mm & 331 & 29 & 347 & 37 & 215 & 21 & 201 & 53 \\
\hline \multicolumn{9}{|c|}{ Painotettu pitoisuus, $\mathrm{mg} \mathrm{I}^{-1}$} \\
\hline Kok-N & 5.8 & 5.4 & 1.1 & 1.6 & 11.2 & 13.1 & 2.0 & 2.3 \\
\hline Kok-P & 0.106 & 0.274 & 0.095 & 0.311 & 0.683 & 1.027 & 0.399 & 0.847 \\
\hline PO4-P & 0.018 & 0.055 & 0.02 & 0.201 & 0.175 & 0.191 & 0.206 & 0.602 \\
\hline Kiintoaine & 228 & 237 & 194 & 132 & 516 & 679 & 254 & 186 \\
\hline \multicolumn{9}{|c|}{ Kuorma, kg ha ${ }^{-1} a^{-1}$} \\
\hline Kok-N & 19.2 & 1.5 & 4.6 & 0.5 & 18.9 & 1.6 & 5.3 & 1.4 \\
\hline Kok-P & 0.38 & 0.06 & 0.33 & 0.1 & 1.75 & 0.19 & 0.84 & 0.44 \\
\hline PO4-P & 0.054 & 0.029 & 0.068 & 0.055 & 0.386 & 0.044 & 0.376 & 0.312 \\
\hline Kiintoaine & 798 & 55 & 682 & 53 & 1209 & 115 & 597 & 110 \\
\hline
\end{tabular}

\section{Ravinne- ja kiintoainehuuhtouma}

\section{Valuntaveden pitoisuudet ennen tuotantosuunnan muutosta ja sen jälkeen}

Tuotantosuunnan muuttumisen vaikutusta koealueiden valuntavesien ravinne- ja kiintoainepitoisuuksiin on tarkasteltu vertaamalla valunnalla painotettuja pitoisuuksia ennen muutosta ja sen jälkeen.

Alueella 1 tuotantosuunnan muutoksen jälkeen tutkituista pitoisuuksista eniten laskivat kokonaistyppipitoisuudet (Taulukko 1a). Nurmiviljelyn vuosien salaojavalunnan valunnalla painotetut typpipitoisuudet olivat $19 \%$ ja pintakerrosvalunnan $29 \%$ viljanviljelyn pitoisuuksista. Salaojavalunnan painotettu kokonaisfosforipitoisuus laski $10 \%$ ja pintakerrosvalunnan nousi $14 \%$ aikaisemmasta jaksosta. Liukoisen epäorgaanisen fosforin $\left(\mathrm{PO}_{4}-\mathrm{P}\right)$ pitoisuudet nousivat. Salaojavalunnan liukoisen fosforin painotettu pitoisuus oli nurmella viljanviljelyyn nähden 1.1-kertainen ja pintakerrosvalunnan 3.7-kertainen. Valumavesien kiintoainepitoisuus puolestaan laski, salaojavalunnan painotettu pitoisuus oli 85\% ja pintakerrosvalunnan 56\% aikaisemmasta.

Myös alueella 2 valumavesien kokonaistyppipitoisuus laski tuotantosuunnan muutoksen myötä selvästi (Taulukko 1b). Salaoja- ja pintakerrosvalunnan painotetut pitoisuudet olivat vajaat 20\% 
aikaisemmasta. Salaojavalunnan kokonaisfosforipitoisuuden painotettu pitoisuus oli muutoksen jälkeen noin $60 \%$ ja pintakerrosvalunnan noin $80 \%$ aikaisemmasta. Tuotantosuunnan muutos nosti pintakerrosvalunnan liukoisen epäorgaanisen fosforin pitoisuuksia. Laidunnusajan pintakerrosvalunnan painotettu pitoisuus oli viljanviljelyjaksoon nähden 3.2-kertainen, ja salaojavalunnan 1.2-kertainen. Laiduntamisen aikainen painotettu kiintoainepitoisuus oli puolestaan salaojavalunnan osalta noin $50 \%$ ja pintakerrosvalunnan vajaat 30\% viljanviljelyn aikaisesta arvosta.

\section{Ravinne- ja kiintoainekuormat}

Ravinne- ja kiintoainehuuhtoumille oli tyypillistä suuret vaihtelut eri vuosien välillä molemmilla koealueilla. Suurimmat kuormitukset muodostuivat kasvukauden ulkopuolella, kevätsulannan ja syksyn runsaiden sateiden aikaan. Valtaosa mitatusta ravinne- ja kiintoainekuormituksesta tuli molemmilta koealueilta salaojien kautta.

\section{Ravinne- ja kiintoainekuormat ennen tuotantosuunnan muutosta ja sen jälkeen}

Muutos viljanviljelystä nurmelle (alue 1) näkyi kokonaistyppikuormien pienenemisenä (Taulukko 1a). Salaojavalunnan Kok-N-kuorma oli nurmiviljelyn vuosina keskimäärin neljännes ja pintakerrosvalunnan kolmannes aikaisemmasta. Salaoja- ja pintakerrosvalunnan yhteenlaskettu Kok-Nkuorma oli nurmiviljelyssä keskimäärin $5 \mathrm{~kg} \mathrm{ha}^{-1} \mathrm{a}^{-1}$, kun se oli viljanviljelyssä ollut noin $21 \mathrm{~kg} \mathrm{ha}^{-1} \mathrm{a}^{-1}$. Nurmiviljelyn vaikutus kokonaisfosforikuormiin oli kahdensuuntainen. Nurmella salaojavalunnan KokP-kuorma oli keskimäärin $85 \%$ viljanviljelyn kuormasta, ja pintakerrosvalunnan puolestaan aikaisempaan nähden noin 1.6-kertainen. Salaoja- ja pintakerrosvalunnan yhteenlasketussa Kok-Pkuormassa ei muutosta juuri tapahtunut, se oli nurmiviljelyssä keskimäärin $0.43 \mathrm{~kg} \mathrm{ha}^{-1}$, kun se oli viljanviljelyn vuosina ollut $0.45 \mathrm{~kg} \mathrm{ha}^{-1}$ (Kuva 1a).

Nurmiviljely lisäsi sekä salaojavalunnan että pintakerrosvalunnan liukoisen epäorgaanisen fosforin kuormia. Salaojavalunnan liukoisen vuotuinen $\mathrm{PO}_{4}$-P-kuorma oli keskimäärin noin 1.3kertainen ja pintakerrosvalunnan noin 1.9- kertainen viljanviljelyyn verrattuna. Keskimääräinen $\mathrm{PO}_{4}$ P:n kokonaiskuorma $(\mathrm{s}+\mathrm{p}) 0.12 \mathrm{~kg} \mathrm{ha}^{-1} \mathrm{a}^{-1}$ oli muutosta edeltävään $\left(0,08 \mathrm{~kg} \mathrm{ha}^{-1} \mathrm{a}^{-1}\right)$ nähden 1.5 kertainen. Ennen muutosta $\mathrm{PO}_{4}$-P:n osuus kokonaisfosforikuormasta oli keskimäärin 21\% ja sen jälkeen 33\%. Tuotantosuunnan muutos näkyi verrattain vähän alueen 1 kiintoainekuormissa. Salaojavalunnan nurmiviljelyn aikainen kiintoainekuorma oli keskimäärin $85 \%$ muutosta edeltäneestä. Pintakerrosvalunnan kuormissa ei ollut käytännössä eroa. Salaoja- ja pintakerrosvalunnan yhteenlaskettu kiintoainekuorma oli nurmiviljelyssä keskimäärin $740 \mathrm{~kg} \mathrm{ha}^{-1} \mathrm{a}^{-1}$, viljanviljelyssä se oli ollut $850 \mathrm{~kg} \mathrm{ha}^{-1} \mathrm{a}^{-1}$.

Alueella 2 siirtyminen viljanviljelystä lihakarjan laidunnukseen vähensi selvästi salaojavalunnan kokonaistyppikuormaa (Taulukko 1b). Laidunnuksen aikana mitattujen salaojavalunnan vuosikuormien keskiarvo oli 28 \% viljanviljelyn aikaisesta. Pintakerrosvalunnan kuorma oli keskimäärin $92 \%$ viljanviljelyn Kok-N-kuormasta. Laidunnurmen Kok-N-kuorma (s+p) oli keskimäärin noin $7 \mathrm{~kg} \mathrm{ha}^{-1} \mathrm{a}^{-}$ ${ }^{1}$, kun se viljalla oli ollut keskimäärin $21 \mathrm{~kg} \mathrm{ha}^{-1} \mathrm{a}^{-1}$. Laidunalueen salaojavalunnan kokonaisfosforikuorma oli $48 \%$ edeltäneestä viljanviljelystä ja pintakerrosvalunnan puolestaan aikaisempaan nähden 2.3-kertainen. Valuntareittien yhteenlaskettu Kok-P-huuhtouma pieneni noin kolmanneksen. Kok-P-kuorman ( $(\mathrm{s}+\mathrm{p})$ keskiarvo oli laidunalueella $1.3 \mathrm{~kg} \mathrm{ha}^{-1} \mathrm{a}^{-1}$, kun se oli viljapellolla ollut keskimäärin $1.9 \mathrm{~kg} \mathrm{ha}^{-1} \mathrm{a}^{-1}$ (Kuva 1b).

Salaojavalunnan mukana kulkeutuneessa keskimääräisessä liukoisen epäorgaanisen fosforin kuormassa ei ollut eroa viljanviljelyn ja laidunnuksen välillä. Kohonneet liukoisen fosforin pitoisuudet nostivat laidunalueen pintakerrosvalunnan keskimääräisen vuosikuorman viljanviljelyyn nähden yli seitsemänkertaiseksi. Liukoisen epäorgaanisen fosforin keskimääräinen vuosikuorma $(\mathrm{s}+\mathrm{p}), 0.69 \mathrm{~kg} \mathrm{ha}^{-}$ ${ }^{1} \mathrm{a}^{-1}$, oli muutosta edeltävään $\left(0.43 \mathrm{~kg} \mathrm{ha}^{-1} \mathrm{a}^{-1}\right)$ nähden 1.6 - kertainen. Viljanviljelyn vuosina $\mathrm{PO}_{4}-\mathrm{P}: \mathrm{n}$ osuus kokonaisfosforikuormasta oli keskimäärin 28\% ja laidunnusvuosina selvästi suurempi, 55\%. Laidunnuksen aikainen salaojavalunnan kiintoainekuorma oli keskimäärin puolet viljanviljelyn vuosikuormista. Pintakerrosvalunnan keskimääräisissä kuormissa ei havaittu muutosta. Valuntareittien yhteenlaskettu keskimääräinen kiintoainekuorma oli laiduntamisen aikana $710 \mathrm{~kg} \mathrm{ha}^{-1} \mathrm{a}^{-1}$, kun se oli viljanviljelyssä ollut $1320 \mathrm{~kg} \mathrm{ha}^{-1} \mathrm{a}^{-1}$. Muutosta edeltävää keskiarvoa nosti vuoden 2008 verrattain suuri kuorma, $2660 \mathrm{~kg} \mathrm{ha}^{-1}$. 

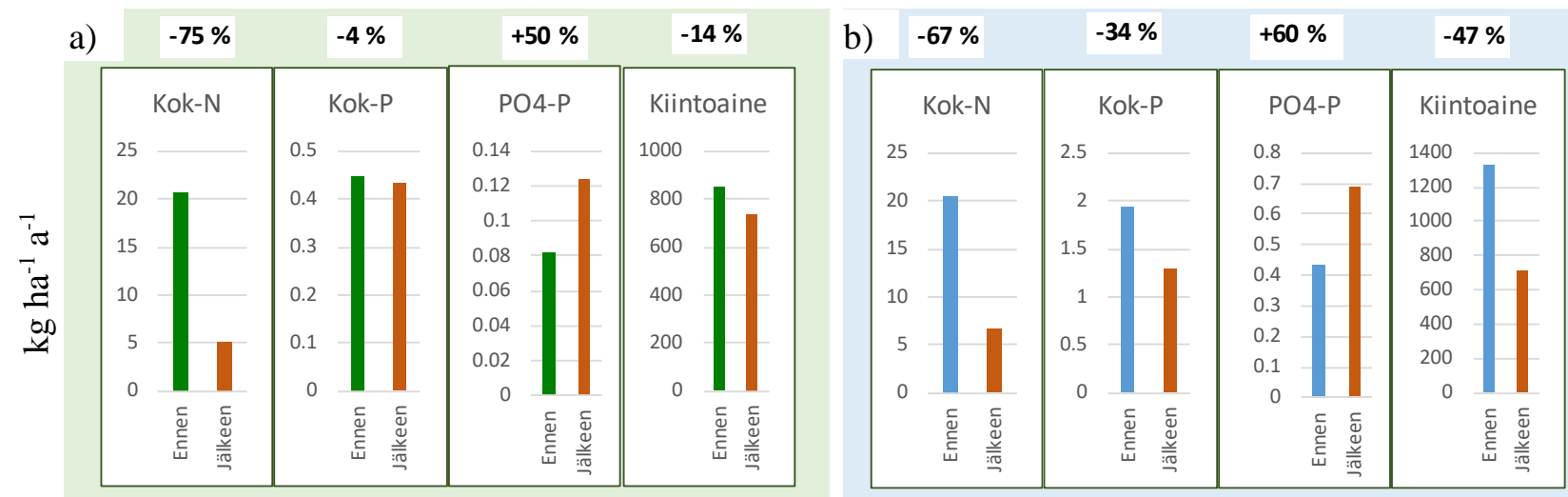

Kuva 1. Alueen 1 (a) ja alueen 2 (b) kokonaistypen (Kok-N), kokonaisfosforin (Kok-P), liukoisen epäorgaanisen fosforin $\left(\mathrm{PO}_{4}-\mathrm{P}\right)$ ja kiintoaineen kokonaiskuormien vuosikeskiarvot ennen tuotantosuunnan muutosta ja sen jälkeen. Alueella 1 vuodet ennen ovat 2008-2011 (vilja) ja jälkeen 2012-2016 (nurmi) ja alueella 2 vastaavat jaksot, 2008-2010 (vilja) ja 2011-2016 (laidun).

\section{Tulosten tarkastelu}

Tutkimuksessa tarkasteltiin viljanviljelystä luonnonmukaiseen nurmiviljelyyn (alue 1) ja nautakarjan laidunnukseen (alue 2) siirtymisen vaikutuksia valuntaan sekä ravinne- ja kiintoainehuuhtoumiin. Alueella 1 vertailtavat jaksot olivat 2008-2011 (vilja) ja 2012-2016 (nurmi), ja alueella 2 vastaavasti 2008-2010 (vilja) ja 2011-2016 (laidun).

\section{Valunta}

Monivuotisella nurmella kokonaisvalunnan (salaoja+pintakerros) osuus sadannasta (valuntakerroin) kasvoi noin 7 prosenttiyksiköllä edeltävään viljanviljelyn jaksoon verrattuna. Pintavalunnan osuus kasvoi suhteessa enemmän kuin salaojavalunnan. Vuosisadannat eivät selitä kokonaisvalunnan kasvua, sillä nurmijaksolla satoi keskimäärin hieman vähemmän (-4\%) kuin viljajaksolla. Monivuotisella nurmikasvustolla pintavalunnan osuuden on todettu olleen nurmella suurempi kuin viljanviljelyssä salaojitetussa savimaassa Lounais-Suomessa (Turtola ja Jaakkola 1995). Muutos nurmiviljelyyn ei juuri vaikuttanut valuntaosuuksiin. Salaojavalunnan osuus sadannasta oli molemmilla tuotantosuunnilla noin $90 \%$.

Alueella 2 (kaltevuus 5\%) laidunnuksen aikainen valuntakerroin oli noin 4 prosenttiyksikköä viljanviljelyä suurempi. Valunnan lisäys johtui pintakerrosvalunnasta, jonka valuntakerroin kasvoi viljanviljelyn aikaisesta 1.6-kertaiseksi. Salaojavalunnan osuus sadannasta ei muuttunut. Tuotantosuunnan muutoksen vaikutus pintakerrosvaluntaan oli jyrkemmällä laidunalueella suurempi kuin loivemmalla nurmialueella. Laidunnuksessa pintakerrosvalunnan osuus kokonaisvalunnasta kasvoi viljanviljelyyn nähden keskimäärin 2.6-kertaiseksi. Jaksojen vuosisadantojen keskiarvot olivat likimain yhtä suuret. Laiduntavien nautojen liikkuminen tiivisti pellon pintaa ja niiden kulkureitit ("polut”) muodostivat näkyviä virtausreittejä pintavalunnalle. Pietola ym. (2005) havaitsivat, että laidunnus vähensi maan infiltraatiokapasiteettia sekä aitosavessa että hiedassa.

Kevätsulannan aikaiset epävarmuudet pintakerrosvalunnan mittauksessa, varsinkin alueella 2, vaikeuttivat jaksojen vertailua. Osaltaan pintakerrosvalunnan kasvuun saattoi vaikuttaa mittauksen kannalta suotuisimpien keväiden sattuminen nurmiviljelyn ja laidunnuksen jaksoille (erityisesti 2012, 2016). Lisäksi vuosien lukumäärät eri tuotantosuunnilla poikkesivat toisistaan ja niiden sääolosuhteet olivat erilaiset. Sadannan ajallinen jakautuminen ja rankkuus sekä lumi- ja routaolot vaikuttivat valunnan muodostumiseen kunkin vuoden aikana.

\section{Ravinne- ja kiintoainehuuhtoumat}

Ravinne- ja kiintoainekuormat viljalla olleilta koelohkoilta olivat ennen tuotantosuunnan muutosta samaa suuruusluokkaa kuin esimerkiksi Jokioisten Nummelan koekentällä vastaavina vuosina (Äijö ym. 2017). 
Nurmiviljelyn myötä alueen 1 valumavesien valunnalla painotetut Kok-N-, Kok-P- ja kiintoainepitoisuudet laskivat, lukuun ottamatta pintakerrosvalunnan Kok-P-pitoisuutta, joka nousi hieman viljanviljelystä. Sen sijaan nurmiviljely nosti $\mathrm{PO}_{4}$-P-pitoisuuksia sekä salaoja- että pintakerrosvalunnassa. Pitoisuuksien nousu yhdessä kasvaneen pintavalunnan kanssa lisäsi $\mathrm{PO}_{4}-\mathrm{P}-$ huuhtoumaa (salaoja+pintakerros) 50\%:lla verrattuna viljanviljelyyn. Nurmea ei lannoitettu, mutta viljapellolle levitettiin fosforilannoitetta keväällä 2007 (10 kg ha-1 P) ja 2009 (11 kg ha-1 P). PO4-Ppitoisuuden nousu viljanviljelystä nurmiviljelyyn siirryttäessä on näkynyt muissakin tutkimuksissa (Ylivainio ym. 2002). Monivuotisen kasvillisuuden peittämillä suojavyöhykkeillä on havaittu korkeita $\mathrm{PO}_{4}$-P-pitoisuuksia pintavalunnassa (Uusi-Kämppä ja Jauhiainen 2010). Samoin korkeita $\mathrm{PO}_{4}-\mathrm{P}-$ pitoisuuksia on mitattu viherkesannolla (Turtola 1992). Epäorgaanista fosforia vapautuu kasvinjäänteistä varsinkin keväisin. Nurmella kiintoainehuuhtouma oli 15\% pienempi kuin viljalla. Kok-P-kuorman vähenemä oli vain $4 \%$. Kasvipeitteisyys suojaa maanpintaa ja sitoo maan rakennetta tiiviimmäksi ja vähentää eroosiota (Turtola 1999). Suurin muutos nurmiviljelyyn siirryttäessä tapahtui kokonaistyppikuormituksessa. Kok-N-kuorma oli keskimäärin vain neljännes viljanviljelyn kuormasta. Osaltaan laskua selittää muutos lannoituksessa. Vuosina 2007-2011 alueelle 1 levitettiin typpilannoitetta n. $130 \mathrm{~kg} \mathrm{ha}^{-1} \mathrm{a}^{-1}$. Vuosina 2012-2016 aluetta ei lannoitettu. Nurmiviljelyssä peltoa ei muokattu, mikä todennäköisesti vähensi mineraalitypen vapautumista maaperästä. Toisaalta sato korjattiin vain kerran kasvukaudessa, jolloin maahan jäi paljon kasviainesta talvea vasten. Turtola (1992) havaitsi, että kesantonurmelta savimaassa typpeä huuhtoutui selvästi vähemmän kuin ohraa viljeltäessä.

Tuotantosuunnan vaihtuminen viljanviljelystä lihakarjan laitumeksi nosti huomattavasti alueen 2 pintakerrosvalunnan $\mathrm{PO}_{4}$-P-pitoisuuksia. Valumavesien muut valunnalla painotetut pitoisuudet (Kok$\mathrm{N}$-, Kok-P- ja kiintoaine) laskivat. Sekä pintakerrosvalunnan että sen $\mathrm{PO}_{4}-\mathrm{P}$-pitoisuuden kasvu johtivat siihen, että liukoisen fosforin huuhtouma kasvoi viljanviljelyyn verrattuna $60 \%$. Alueella 2 aluetta 1 enemmän kasvaneeseen pintakerrosvalunnan $\mathrm{PO}_{4}$-P-pitoisuuteen vaikutti karjanlannan fosforimäärä, jonka arvioitiin olleen noin $10 \mathrm{~kg} \mathrm{ha}^{-1} \mathrm{a}^{-1}$. Viljanviljelyn vuosina (2007-2010) fosforilannoitetta levitettiin keväällä $2008\left(14 \mathrm{~kg} \mathrm{ha}^{-1} \mathrm{P}\right)$ ja $2010\left(8 \mathrm{~kg} \mathrm{ha}^{-1} \mathrm{P}\right)$. Laitumen viljanviljelyä noin kolmanneksen alhaisempi Kok-P-kuorma johtui pääosin salaojavalunnan pienemmistä pitoisuuksista, sillä pintakerrosvalunnan Kok-P-kuorma kasvoi tuotantosuunnan muutoksen jälkeen. Myös alueella 2 kasvipeitteisyyden eroosiota vähentävä vaikutus johti aiempaa pienempiin kiintoainepitoisuuksiin ja kuormiin (-47\%). Jyrkemmällä alueella 2 ero aikaisempaan viljanviljelyyn oli suurempi kuin alueella 1. Muutos viljanviljelystä laidunalueeksi vähensi kokonaistyppihuuhtoumaa lähes $70 \%$ valumavesien pitoisuuksien laskusta johtuen, samoin kuin alueella 1. Syynä tähän oli kivennäislannoituksen ja osaltaan myös muokkauksen lopettaminen, mutta toisaalta karjan lannasta ja virtsasta tuli typpeä. Typpilannoitetta levitettiin vuosina 2007-2010 viljoille keskimäärin $130 \mathrm{~kg} \mathrm{ha}^{-1} \mathrm{a}^{-1}$. Tulokset laidunnuksen vaikutuksesta ravinne- ja kiintoainekuormitukseen olivat yhdenmukaisia aiemmin saatujen tutkimustulosten kanssa (Saarijärvi ym. 2006, Uusi-Kämppä ja Jauhiainen 2010).

\section{Johtopäätökset}

Yhdeksän vuoden seuranta kahdella salaojitetulla peltolohkolla osoitti, että peltoalueen tuotantosuunnalla (vilja, nurmi ja laidun) oli vaikutusta sieltä tulevaan kokonaisvaluntaan ja valuntareitteihin sekä erityisesti valumavesien ravinne- ja kiintoainepitoisuuksiin ja siten kuormitukseen. Valtaosa mitatusta valunnasta ja kuormituksesta purkautui salaojien kautta sekä suhteellisen loivalta (kaltevuus 1\%) että jyrkältä (kaltevuus 5\%) lohkolta kaikilla tuotantosuunnilla.

Muutos tavanomaisesta viljanviljelystä luonnonmukaisesti viljellylle monivuotiselle nurmelle (ei lannoitusta eikä muokkausta) näkyi selvimmin kokonaistypen huuhtouman vähenemisenä ja liukoisen epäorgaanisen fosfaattifosforin huuhtouman kasvuna. Kiintoainehuuhtoumissa oli nähtävissä lievää laskua. Kokonaisfosforin huuhtouminen pysyi lähes ennallaan.

Muutos viljanviljelystä luonnonmukaiseen lihakarjan laidunnukseen vaikutti ainepitoisuuksiin ja -kuormiin samansuuntaisesti kuin siirtyminen nurmiviljelyyn. Laidunalueella kokonaistypen huuhtoumat vähenivät huomattavasti. Myös kiintoainekuorma pieneni. Liukoisen epäorgaanisen fosfaattifosforin $\left(\mathrm{PO}_{4}-\mathrm{P}\right)$ huuhtouma pintavalunnassa kasvoi suhteellisesti nurmiviljelyä enemmän. Kokonaisfosforin huuhtouma oli kuitenkin pienempi kuin viljanviljelyssä, jossa kiintoaineeseen sitoutunut fosfori muodosti valtaosan suuren osan kokonaisfosforikuormasta. 
Peltolohkotasolla ja erilaisina hydrologisina vuosina tehdyt mittaukset osoittivat selvästi tuotantosuunnan muutosten vaikutukset ravinne- ja kiintoainehuuhtoumiin. Tutkimus jatkuu, jotta saadaan kattavampaa tietoa nurmiviljelyn ja laidunnuksen toimenpiteiden, esim. nurmen uusimisen, vaikutuksista sekä typen kaasumaisista häviöistä ja ravinnetaseista.

\section{Kiitokset}

Tutkimusta ovat rahoittaneet Salaojituksen Tukisäätiö sr ja hankkeessa mukana olleet laitokset. Vuosina 2007-2013 rahoittajana oli myös maa- ja metsätalousministeriö ja 2011-2013 Maa- ja vesitekniikan tuki ry.

\section{Kirjallisuusviitteet}

Nurminen, J., Paasonen-Kivekäs, M. \& Vakkilainen, P. 2007. Siuntion Kirkkojoen veden laadun seurantatutkimus 2005. Teknillinen korkeakoulu. Vesitalouden ja vesirakennuksen laboratorio. $48 \mathrm{~s}$.

Nurminen, J. ym. 2018. Mittaustuloksia Gårdskulla Gårdin koekentältä - ravinne- ja kiintoainekuormat tuotantosuunniltaan erilaisilta pelloilta. Salaojituksen tutkimusyhdisty ry. Käsikirjoitus.

Pietola, L., Horn, R. \& Yli-Halla, M. 2005. Effects of trampling by cattle on the hydraulic and mechanical properties of soil. Soil \& Tillage Research 82: 99-108.

Saarijärvi, K., Karppinen, M., Uusi-Kämppä, J., Turtola, E. \& Virkajärvi, P. 2006. Laitumen fosforitalous ja vesistökuormituksen hallinta. In: Alakukku, L. (toim.). Maaperä prosessit - pellon kunnon ja ympäristönhoidon perusta. MMM:n maaperätutkimusohjelman loppuraportti. Maa- ja elintarviketalous 82. 2336.

Seppälä, I. 2017. Kandidaatintyö. Aalto-yliopisto, Insinööritieteiden korkeakoulu, 29 s.

Turtola, E. 1999. Phosphorus in surface runoff and drainage water affected by cultivation practices. Väitöskirja. Maa- ja elintarviketalouden tutkimuskeskus. $108 \mathrm{~s}$.

Turtola, E. 1992. Kesannointimenetelmän vaikutus typen ja fosforin huuhtoutumiseen. In: Rekolainen, S.\& Kauppi, L. (toim.). Maatalous ja vesien kuormitus. Yhteistutkimusprojektin tutkimusraportit. Vesi- ja ympäristöhallituksen monistesarja 359: 135-145.

Turtola, E. \& Jaakkola, A. 1995. Loss of phosphorus by surface runoff and leaching from a heavy clay soil under barley and grass ley in Finland. Acta Agriculturae Scandinavica, Section B-Soil and Plant Science 45: 159-165.

Turunen, M., Warsta, L., Paasonen-Kivekäs, M., Nurminen, J., Alakukku, L., Myllys, M. \& Koivusalo, H., 2015. Effects of terrain slope on long-term and seasonal water balances in clayey, subsurface drained agricultural fields in high latitude conditions. Agricultural Water Management 150: 139-151.

Turunen, M., Warsta, L., Paasonen-Kivekäs, M. \& Koivusalo, H. 2017. Computational assessment of sediment balance and suspended sediment transport pathways in subsurface drained clayey soils. Soil \& Tillage Research 174: 58-69.

Uusi-Kämppä, J. \& Jauhiainen L. 2010. Long-term monitoring of buffer zone efficiency under different cultivation techniques in boreal conditions. Agriculture, Ecosystems and Environment 137: 75-85.

Vakkilainen, P., Alakukku, L., Myllys, M., Nurminen, J., Paasonen-Kivekäs, M., Peltomaa, R., Puustinen, M. \& Äijö, H. 2008. Pellon vesitalouden optimointi. Väliraportti 2008. Salaojituksen tutkimusyhdistys ry:n tiedote 29. $100 \mathrm{~s}$.

Vakkilainen, P., Alakukku, L., Myllys, M., Nurminen, J., Paasonen-Kivekäs, M., Peltomaa, R., Puustinen, M. \& Äijö, H. 2010. Pellon vesitalouden optimointi. Loppuraportti 2010. Salaojituksen tutkimusyhdistys ry:n tiedote $30.114 \mathrm{~s}$

Vento, T. 2008. Siuntion Kirkkojoen ravinnekuormitus. Kandidaatintyö. Teknillinen korkeakoulu.

Ylivainio, K., Esala, M. \& Turtola E. 2002. Luonnonmukaisen ja tavanomaisen viljelyn typpi- ja fosforihuuhtoumat, Jokioinen. Maa- ja elintarviketalouden tutkimuskeskus. Maa- ja elintarviketalous $12.74 \mathrm{~s}$.

Äijö, H., Myllys, M., Nurminen, J., Turunen, M., Warsta, L., Paasonen-Kivekäs, M., Korpelainen, E., Salo, H., Sikkilä, M., Alakukku, L., Koivusalo, H. \& Puustinen, M. 2014. Salaojitustekniikat ja pellon vesitalouden optimointi. Loppuraportti 2014. Salaojituksen tutkimusyhdistys ry:n tiedote $31.126 \mathrm{~s}$.

Äijö, H., Myllys, M., Sikkilä, M., Salo, H., Nurminen, J., Häggblom, O., Turunen, M., Paasonen-Kivekäs, M., Warsta, L., Koivusalo, H., Alakukku, L. \& Puustinen, M. 2017. Toimivat salaojitusmenetelmät kasvintuotannossa (TOSKA). Loppuraportti 2017. Salaojituksen tutkimusyhdistys ry:n tiedote 32. $109 \mathrm{s.}$ 